\title{
A Shift in Values: Non-commodity Resource Management and the Forest Service
}

\author{
Timothy J. Farnham, Cameron Proffitt Taylor, and Will Callaway
}

\begin{abstract}
Quantitative indicators of change for non-commodity resource management were examined, to assess whether the United States Department of Agriculture Forest Service has been changing its on-the-ground management practices to give more emphasis to non-commodity resources. Specifically, data on recreation management and on wildlife and fish habitat management were analyzed to determine whether any shifts in the agency's management priorities had occurred. All data examined indicate that the Forest Service has been increasing its activities in non-commodity resource management over historic levels. When viewed in context with other recent studies suggesting that the Forest Service is moving away from traditional commodity production, the results of this study provide evidence that a significant shift has occurred, or presently is occurring, in Forest Service management practices.
\end{abstract}

Critics long have charged that the United States Forest Service historically has emphasized commodity uses of the National Forests, such as timber, grazing, hunting, and fishing, and that it has paid too little attention to both the biological richness of the national forests and their true value as a non-consumptive recreational resource (Twight, 1983; Ackerman, 1990). However, with the completion of several recent studies documenting change in the Forest Service-including studies on employee perceptions of change (Mohai, Stillman, Jakes, \& Liggett, 1994), the agency's workforce diversification efforts (Thomas \& Mohai, 1995), and changes in budget requests and appropriations (Farnham, 1995)-there is reason to explore whether a shift in management emphasis has occurred in the Forest Service. This paper is an attempt to evaluate agency activity in the important non-commodity areas of recreational and wildlife uses of the National Forests. In contrast to a review of officially stated Forest Service policies, this study concentrates on quantitative data to assess actual on-theground changes in management.

It should be noted that although changes in chosen indicators of recreation and wildlife management will not reveal cause and effect relationships of change by themselves, nevertheless they would indicate that a shift in management emphasis is occurring. In addition, the data presented must be taken in their entirety. The individual statistics alone do not give evidence for change; rather, their collective presentation will demonstrate whether a significant shift in on-the-ground management practices has occurred.

In particular, this study will focus first on Recreation Management through a data analysis of indicators, including recreation visitor days, maintenance and construction funds, recreation receipts, recreation personnel, wilderness acreage designated, and Wild and Scenic river miles designated. The analysis of Wildlife and Fish Habitat Management includes data on total acres of habitat improved, total number of structures installed to support wildlife, new funding mechanisms, and examples of new management programs. 


\section{Recreation Management}

This section analyzes recreation demands on National Forest lands and the agency's response to those demands. The analysis was conducted based on recreation management information compiled in the annual Reports of the Forest Service, Fiscal Years 1981-1991 (United States Department of Agriculture, Forest Service, 19811992), annual Forest Service budget tables, and programs and policies put forth by the Forest Service Recreation Management Staff. Additional information was collected via interviews with Forest Service staff. Information on full-time equivalents was gathered from the Forest Service Office of Program Development and Budget, in Washington, DC, to determine the number of staff detailed to recreation activities. Finally, reports published by the Congressional Research Service and by the General Accounting Office, as well as congressional testimony, were used to supplement the quantitative data. In some instances, different time periods are used in presenting the data because the Forest Service has changed data collection methods or categories in recent years.

\section{Recreation Programs}

A recent study by the American Recreation Coalition (1991) noted that recreational demands continue to increase as Americans have more expendable income and more leisure time. The survey also noted that $54 \%$ of Americans have visited public lands in the past two years. This increased visitation is expected to continue. The trend is similar for National Forest lands. Of all the federal land management agencies, the Forest Service continues to report more visitors each year than any other agency (United States Department of Agriculture, Forest Service, 1981-1992). National Forest visitors come to enjoy recreation opportunities such as camping, hiking, boating, and other forms of mechanized travel, sightseeing, hunting, fishing, and others. In general, the Forest Service defines recreation as activities that do not involve extraction of resources such as timber, minerals, gas, etc. The Forest Service measures recreation use in "recreation visitor days" (RVDs), each of which represents one person spending twelve hours or twelve persons spending one hour each (or the equivalent) involved in recreation on Forest Service lands.

Recreation visitor days on National Forest lands have increased steadily since 1985, according to Forest Service annual Reports for 1980-1991 (Figure 1). Concomitant with this increase in recreation visitor days has been a continuous increase in non-consumptive activities-such as sightseeing, camping, and hiking-while consumptive activities (hunting and fishing) have remained steady. Much of the increase in non-consumptive activities has come from sightseeing, both motorized and non-motorized.

Funding for the Recreation Management program also has risen during this period. In real 1992 dollars, total Recreation funding has grown over 50\%, from $\$ 140$ million in 1983 to $\$ 216$ million in 1992 (Farnham, 1995). Initially, in the first half of the 1980s, appropriations had been decreasing, as had Forest Service budget requests. Particular sections of the Recreation budget show trends similar to the overall budget. For both trail construction and trail maintenance (Figures $2 \mathrm{a}$ and $2 \mathrm{~b}$ ), requests and appropriations decreased until 1985-1986. By 1991, funds had increased significantly. Recreation construction, which entails all campsite and facility construction and reconstruction, experienced substantial appropriations increases through the 1980s (Figure 2c). By 1991, funds had increased almost ten times over what they had been in 1982. These appropriations occurred in response to Forest Service requests to address backlogs and to efforts by members of Congress to fund specific projects in their 
Symposium on Forest Service: Farnham/Taylor/Callaway

districts or states (Farmer, 1993). Similar increases for these reasons have been noted in trail construction and maintenance.

Despite the increase in recreation visitor days and general funds available to the Forest Service in recent years, backlogs for recreation, such as facility maintenance or trail reconstruction, have become severe. The annual Reports note that trail

\section{Figure 1}

Recreation Visitor Days in the National Forests

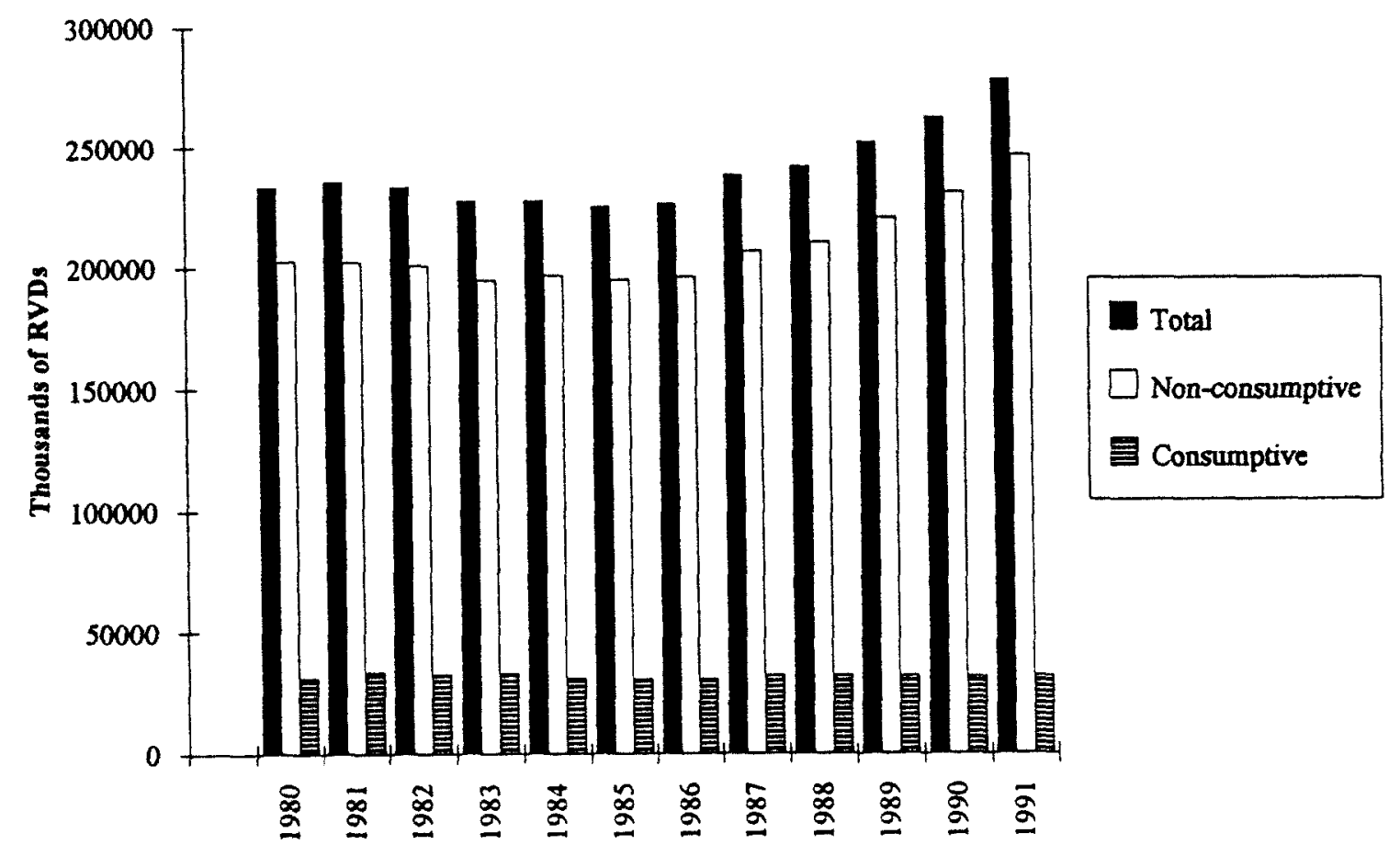

\section{Figure 2a}

Trail Construction Funds for the National Forests

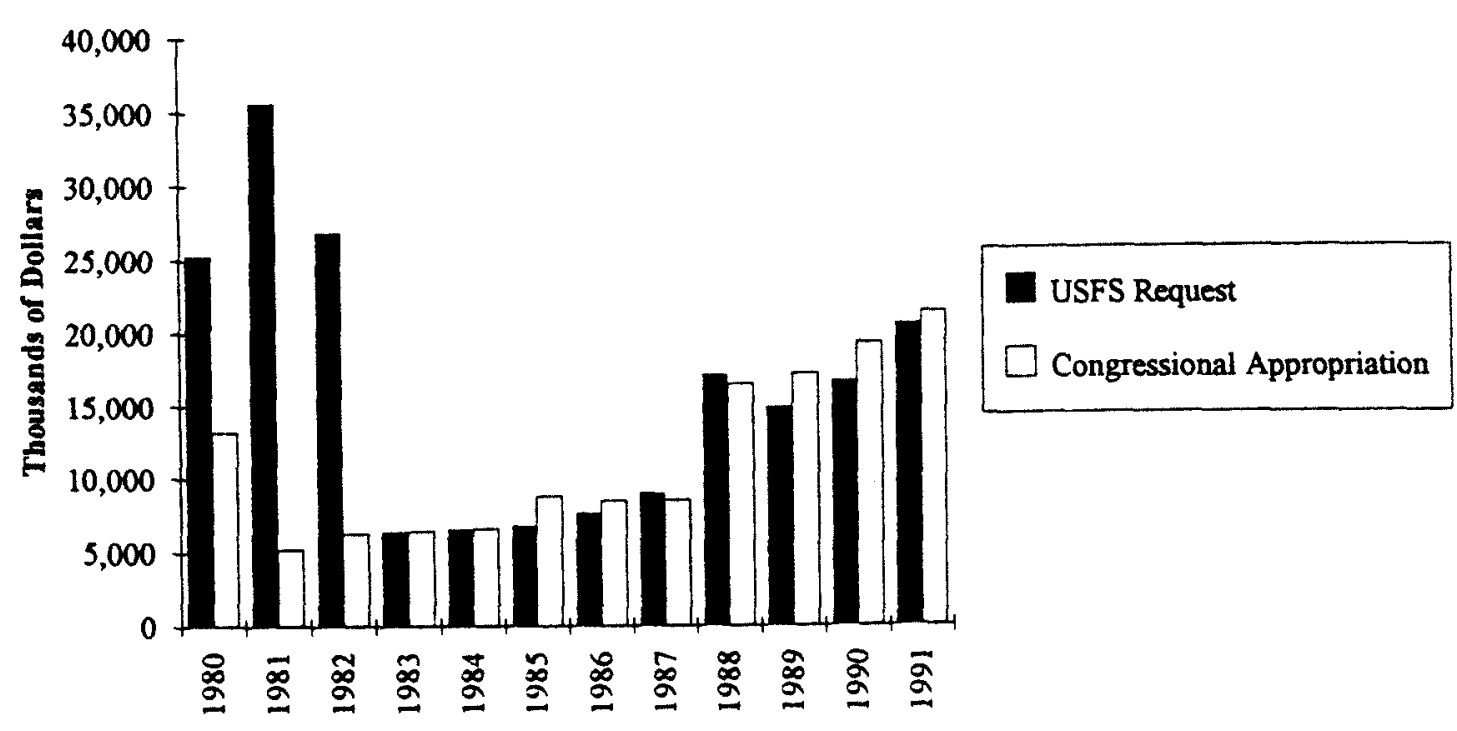




\section{Figure 2b}

\section{Trail Maintenance Funds for the National Forests}

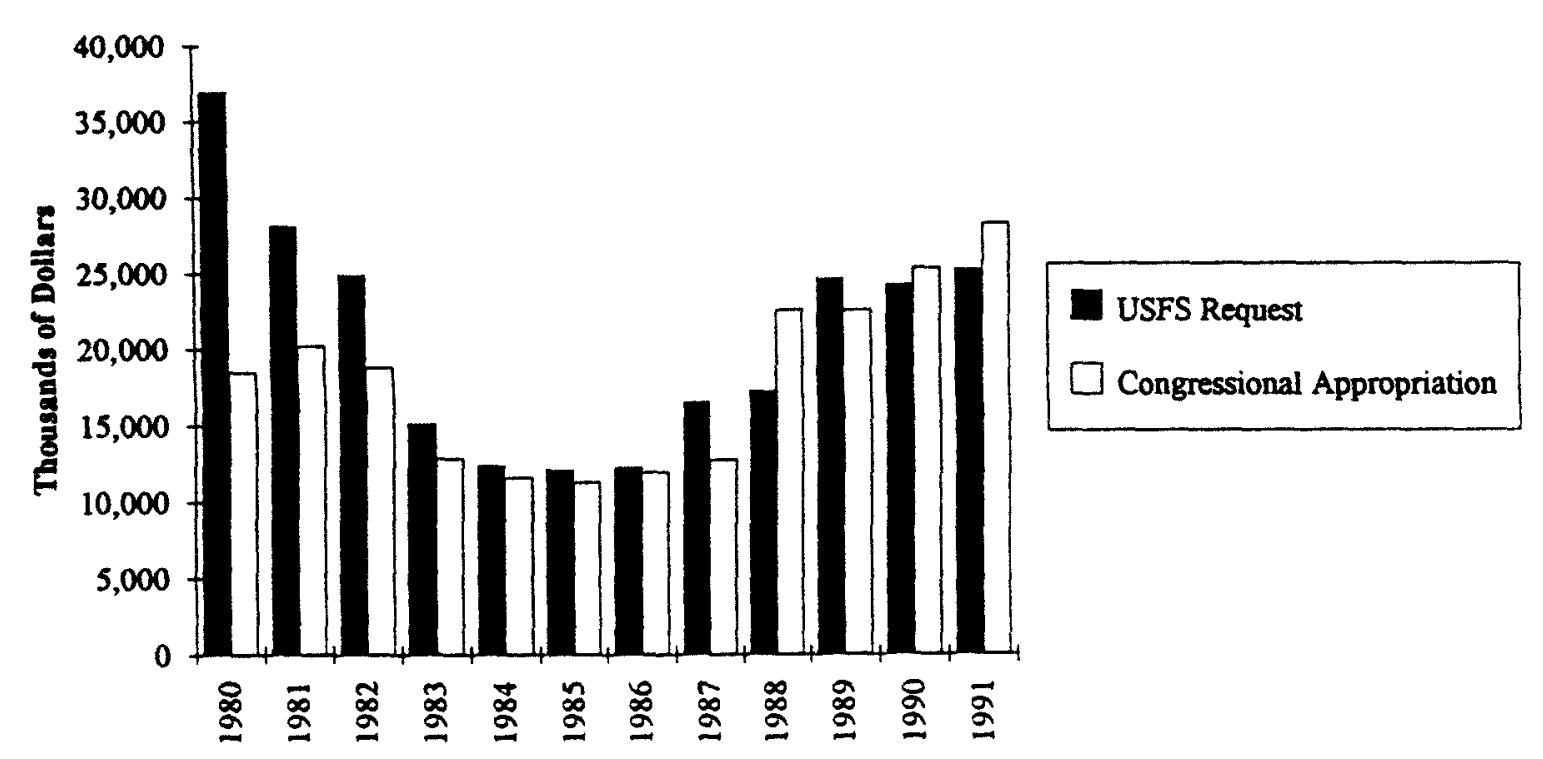

Figure 2c

Recreation Construction Funds for the National Forests

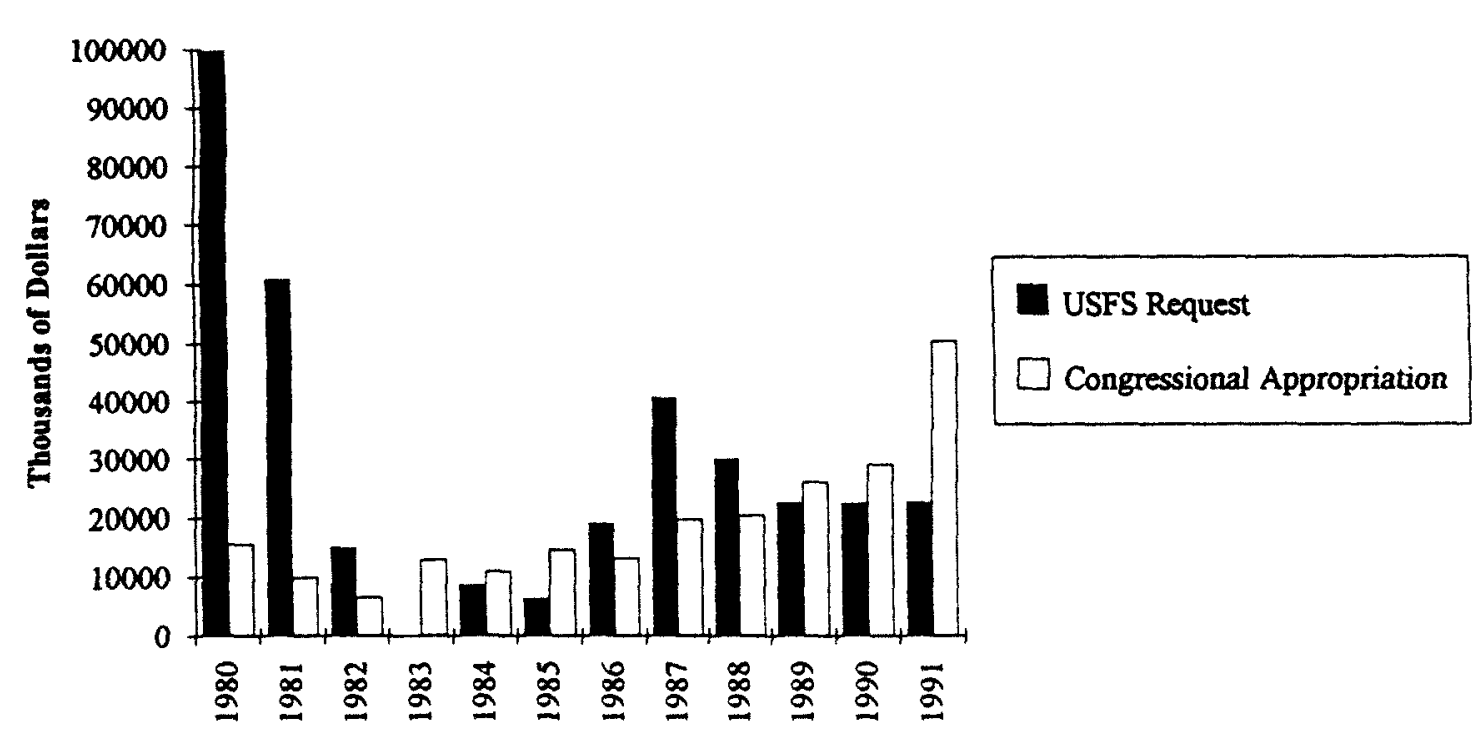

construction and maintenance have fallen below the goals established during the period from 1984 to 1991 (Figure 3) by the Forest Service's planning efforts, as outlined in the Forest and Rangelands Renewable Resources Planning Act of 1974 (RPA). The exception to this occurs in 1986 and 1987 when, for undetermined reasons, the Forest Service listed "low-bound" targets only. This did not mean that the backlogs ceased to exist, only that the Forest Service was establishing lower targets in accordance with expected funding. It becomes obvious that backlogs were increasing when considering the 1988 and 1989 targets. Although 1990 and 1991 targets do not include reconstruction targets, but only maintenance, it still is apparent that backlogs were not being addressed fully, largely due to lack of funds.

Former Forest Service Chief Dale Robertson noted in a recent interview that backlogs have been given second priority, while operation and new construction were of 
primary importance (Robertson, 1992). Robertson also noted that "high-bound" funding requests (Forest Service targets that assume full funding is possible), as outlined by the RPA documents, would have addressed the backlogs much more quickly. However, even though funding is at unprecedented levels, tight budgets have prevented these needs from being addressed.

The 1990 RPA planning documents predicted that recreation-user demands would continue to increase, with an estimate of 308 million recreation visitor days in 1995 (United States Department of Agriculture, Forest Service, 1981-1992 [1991]). With this expected increase, the RPA reports that the Forest Service will make efforts to upgrade facilities, reduce backlogs, and make all recreation programs, facilities, and services readily accessible for all visitors. This statement corresponds with President Bush's 1991 program, America's Great Outdoors, which concentrated on interpretation/education services, facilities improvement, and the establishment of special areas for recreation. Given the current environment in Washington, DC, however, budget cuts for the Forest Service and federal agency downsizing may threaten any momentum these efforts have gained in recent years.

\section{Figure 3}

Trail Construction and Maintenance vs. RPA Targets

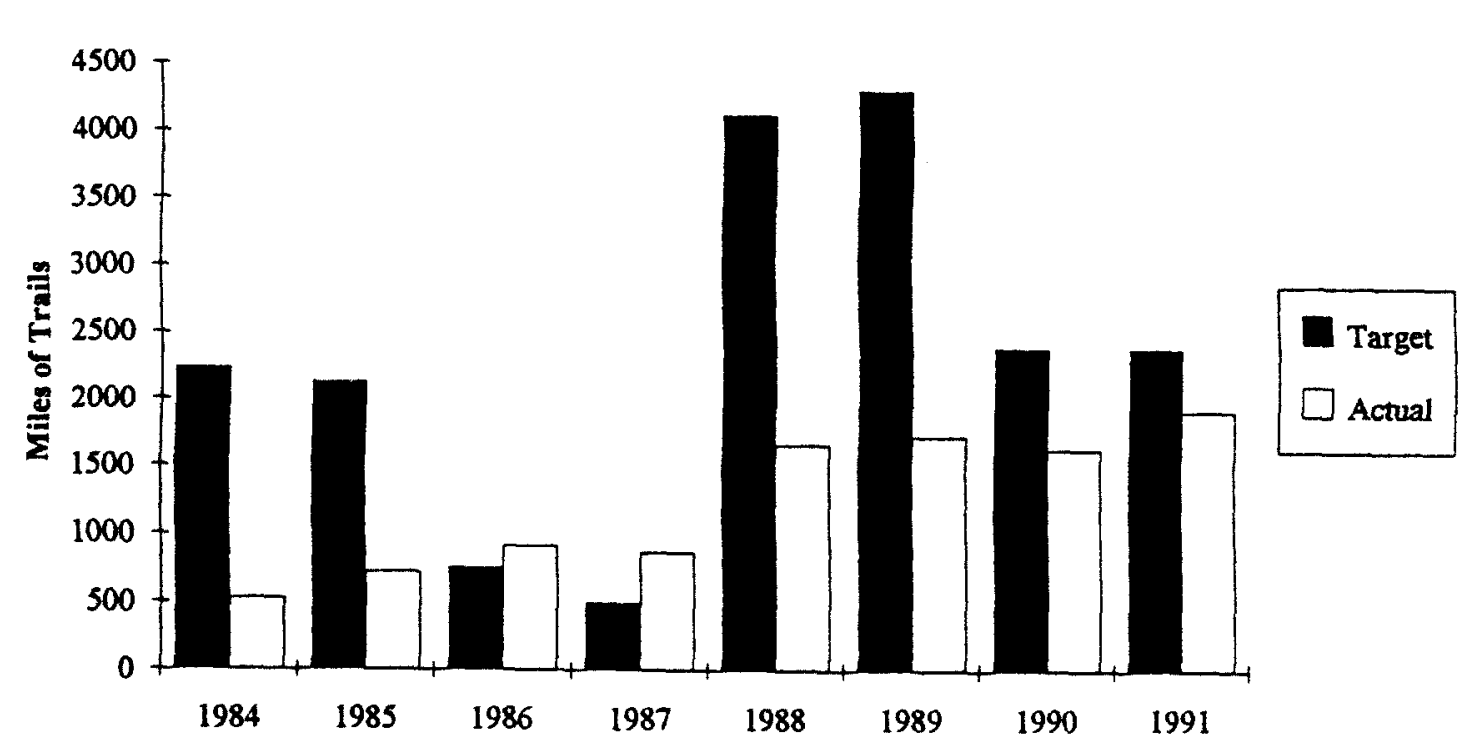

\section{Alternative Funding Mechanisms}

Increased funds for recreation have been accompanied by increased revenues from recreation activities. These revenues come from permitting concessionaires to provide recreation activities, such as skiing or guided trips, and from user fees charged to recreationists for various activities such as use of campsites or other developed facilities (United States Department of Agriculture, Forest Service, 1981-1992 [1991]). During the 1980s, receipts climbed from approximately \$28 million in 1981 to $\$ 43$ million in 1991 (Table 1). The steady increase reflects the Forest Service's efforts to increase receipts from activities in the National Forests.

User fees from recreation activities grew slowly over the past decade (Table 1). Increased user fees often have been opposed by Congress, as noted by report language accompanying the fiscal year 1984 appropriations bill that prevented fee increases greater than 50\% above previously-established fees (United States Congress, 1983). Often the fees have been increased through cooperation on the part of the National Forest users, as is noted in the report language accompanying the fiscal year 1989 
appropriations bill, which allowed a phase-in of fee increases according to the agreement worked out by the Forest Service and various National Forest user groups (United States Congress, 1988a). Increased fees often have been supported by the administration as a means of increasing Forest Service revenues. The 1985 RPA recommended increased user fees as a means of offsetting increasing costs associated with recreation programs (United States Congress, 1987).

\section{Table 1}

\section{National Forest Recreation Receipts (in Thousands of Dollars)}

\begin{tabular}{lcc}
\hline Year & Total Receipts & User Fees \\
1981 & 28,503 & \\
1982 & 35,822 & \\
1983 & 37,837 & \\
1984 & 36,051 & 11,900 \\
1985 & 38,906 & 12,100 \\
1986 & 37,783 & 10,900 \\
1987 & 36,542 & 11,100 \\
1988 & 39,247 & 12,500 \\
1989 & 41,716 & 14,000 \\
1990 & 42,616 & 14,000 \\
1991 & 43,031 & 15,000 \\
\hline
\end{tabular}

In addition to increasing revenues through concession contracts and user fees, the Forest Service formulated the National Recreation Strategy in 1988 to bring in partners to offset costs while enhancing recreation opportunities (United States Congress, 1988b). Under these programs, private and non-profit groups joined with the Forest Service to help in "developing, repairing, and operating" recreation areas and to provide recreation opportunities (United States General Accounting Office, 1991). The cost-shares are designed to provide additional funding and staffing for Forest Service projects that otherwise might not have received funding. The partnerships allow private enterprise to operate on the National Forest lands and to provide recreation services that are needed but cannot be provided by the Forest Service. These services include hunting guides, river outfitters, trail building, campsite improvement, or other recreation needs not provided fully by Forest Service personnel. These cost-share programs generated over \$25 million for recreation programs between 1988 and 1991.

\section{Personnel}

The Forest Service measures staff assigned to various programs by full-time equivalents (FTEs). An FTE is defined by the Forest Service as one individual working full-time for one year, based on 2,087 hours per year representing the effort of a fulltime employee (United States Department of Agriculture, 1993). The percentage of Recreation FTEs as a function of overall Forest Service FTEs from 1981 to 1991 is represented in Table 2. The trend from 1985 to 1991 was an increase, from $5.71 \%$ of the total workforce to $7.51 \%$. Because the Forest Service averaged around 37,516 FTEs annually during that time, the change of 1.8 percentage points represents a total of 675 FTEs added to the recreation program since 1985. Thomas and Mohai (1995) provide a more extensive study of changes in Forest Service personnel. 
Table 2

\section{Recreation FTE Percentage of Total Forest Service}

$\begin{array}{cc}\text { Year } & \text { Percentage } \\ 1981 & 6.40 \\ 1982 & 5.90 \\ 1983 & 6.25 \\ 1984 & 5.87 \\ 1985 & 5.71 \\ 1986 & 5.91 \\ 1987 & 6.40 \\ 1988 & 6.83 \\ 1989 & 6.87 \\ 1990 & 6.80 \\ 1991 & 7.51\end{array}$

\section{Wilderness}

Visitor days in wilderness areas have fluctuated since 1981, but were at an alltime high of 12.8 million in 1991. This general increase has been accompanied by an increase in wilderness designations by Congress that exceeded the initial recommendations made by the Forest Service in their Roadless Area Review and Evaluation (RARE II) issued in 1979 (Congressional Research Service, 1989). At that time the Forest Service recommended that 15 million acres be designated as wilderness, and noted that 11 million additional acres needed further study before recommendations could be made. The RARE II study looked at a total of 62 million acres, as instructed by Congress in NFMA, and recommended that an additional 36 million acres be left open for multiple-use management.

A substantial increase in designations occurred in 1981 and 1984. The 1984 increase can be attributed to numerous members of Congress seeking to get wilderness designations in their states during the twentieth anniversary of the Wilderness Act (Twiss, 1993). The increase in 1981 is attributed to completion of both RARE II and a large number of management plans in 1980.

Congress's total designations of nearly 19 million acres since 1980 have included lands that were recommended as well as lands that were not included in RARE II recommendations (Congressional Research Service, 1989). Although the initial recommendations of RARE II were challenged in a California district court, and the state won the case, the recommendations have remained largely unchanged ( $C A v$. Block; CA v. Berglund). Following an agreement reached in the Congress in 1984 by Senator Jim McClure (R-ID) and Representative Ron Seiberling (R-WY), reevaluation of the lands was deemed unnecessary, and Congress proceeded to designate wilderness areas largely on a state-by-state basis.

Once designated, management of wilderness lands falls to the Forest Service. At oversight hearings on Forest Service wilderness management held before the Committee on Energy and Natural Resources of the United States Senate in 1988, initial management efforts in many regions were noted as nothing more than "benign neglect," and it was suggested that without the direction of Congress following NFMA, the Forest Service likely would not have carried out RARE II (United States Congress, 1988c, p. 135). Forest Service wilderness rangers who testified at the wilderness 
oversight hearing recognized the need for basic improvements in training sessions, environmental education, and career development for Forest Service employees.

At the same hearing, the Associate Chief admitted that of 900 employees in the Washington office of the Forest Service only one worked full-time on wilderness management. However, he did detail the efforts of the Intermountain Forest and Range Experiment Station in Montana, which was designated as a wilderness training center in 1987 in recognition of the need for greater wilderness training. The station now is responsible for primary research and nationwide education in wilderness management (United States Congress, 1988c). Since 1986, the number of recreation personnel with wilderness responsibilities has increased, and specific wilderness management methods are outlined in the Wilderness Management Handbook designed and last updated by the Forest Service in 1986 (Twiss, 1993). The Handbook outlines the resources that need to be protected in wilderness areas and establishes limits of acceptable change, related primarily to heavy recreational traffic. With increased personnel training and attention paid to wilderness areas, it is apparent that wilderness management is attaining an increasingly important role in the recreational management program.

\section{Wild and Scenic Rivers}

The designation of Wild and Scenic Rivers and their management has followed a path similar to that of wilderness. Following NFMA, the Forest Service was directed to complete reviews of rivers or river segments eligible for designations as wild, scenic, or recreational rivers (Wild and Scenic Rivers Act, 1968, as amended by P. L. 98-11, 16 U.S.C. 1241 et seq.). Unlike the wilderness recommendations, the Forest Service has ongoing studies of rivers and river segments and reports to Congress with their recommendations when studies are complete. Between 1979 and 1991, Congress designated 2,758 miles of river to be protected under the Wild and Scenic Rivers Act. A dramatic increase in the number of rivers designated in 1988 can be attributed to members of Congress working to have designations made during the 20th anniversary year of the Wild and Scenic Rivers Act (Lundeen, 1993). Otherwise, recommendations for Wild and Scenic designation, much like wilderness, often are made by the Forest Service following completion of general management plans. Still, this point should not diminish the fact that Wild and Scenic River miles have more than quadrupled in the last ten years.

\section{Wildlife and Fish Habitat Management}

From increases in recreation visitor days, to increases in funding, to increases in designated wilderness and in Wild and Scenic Rivers, it is apparent that recreation management in the National Forests has been going through some changes in the past decade. This next section will attempt to measure change in another of the Forest Service's important non-commodity management programs-Wildlife and Fish Habitat Management-by tracking quantitative indicators through document analysis of Forest Service Annual Reports (1980-1991) and other literature provided by the Forest Service. Interviews with individuals who have worked for and with the Forest Service also were conducted, and interest group literature was surveyed. Quantitatively, a number of indicators were assessed: total acreage of wildlife habitat improved and structures installed to support wildlife; a breakdown of habitat improved by program area; regional trends; and the amount of funding and number of cooperators involved in the innovative Challenge Cost-Share Program. For the purpose of analysis, wildlife, fish, and threatened, endangered, and sensitive species have been broken into three 
program areas. Wildlife and fish include both game species and non-game species that are not threatened or endangered. These indicators were tracked from 1980 to 1991.

The limitations of such an analysis are numerous. Different National Forests have different types of wildlife, with varying needs. Therefore, each Forest has its own set of requirements regarding wildlife habitat. In addition, depending on the region and other management activities taking place, the type of required habitat management varies. As Farnham (1995) notes, funding is a useful indicator in evaluating change; however, it is difficult to track whether the Forest Service or an individual Forest is employing funds effectively. Lastly, the numbers needed for analysis often are not recorded nor reported consistently throughout the National Forest System.

\section{Wildife and Fish Program}

Many species, from the controversial spotted owl to the common songbird, are dependent upon the National Forests for survival. As private land increasingly is converted into agricultural, industrial, and urban areas, the National Forest System will become important to an even greater variety and abundance of wildlife species (Rice, 1990). Critics assert that pressure upon and the disturbance of limited resources, resulting from activities such as hunting, fishing, and timber harvesting, make the National Forests an unsafe haven both for non-game species and for threatened and endangered species (Rice, 1990). In the Pacific Northwest, nearly $70 \%$ of the remaining habitat for the northern spotted owl is found in the National Forest System. However, the importance of these lands to other non-game species cannot be underemphasized. For example, large unbroken forests found only on public lands are particularly important to the continued survival of songbirds, who use them as nesting grounds during the spring on their migratory route north (Rice, 1990).

The Forest Service insists that its Wildlife and Fish Program, through its four management tasks--inventorying, coordinating with state agencies, improving and restoring habitats, and monitoring and reporting-is designed to provide for recovering populations of threatened and endangered species, as well as ensuring productivity of selected species for recreational and commercial uses (United States Department of Agriculture, Forest Service, 1992). Due to the fact that $40 \%$ of the program's resources were allocated to the task of improving and restoring habitat in 1992 (Darden, 1993), this section will analyze primarily habitat improvement activities.

Specific to the "improve and restore" task, we have attempted to analyze two related factors: First, whether there has been a change in habitat improvement methods related to timber management-mitigating the effects of methods such as clearcutting and harvesting, to enhance early successional growth (i.e., young tree growth for species such as deer); and second, whether non-game wildlife habitat has begun to receive as much attention as has game species habitat. Since both game and non-game species are grouped together under the wildlife and fish headings, numbers for such an analysis are unavailable. Therefore, for the purposes of this study, numbers for threatened, endangered, and sensitive species will be analyzed, to assess the agency's commitment to non-game species.

\section{Habitat Improvement Trends}

In February 1992, the Forest Service described its improvement practices as restoring ecosystem functions, protecting special habitats, and developing food, cover, and water sources (United States Department of Agriculture, Forest Service, 1992). There are two approaches-direct and indirect-to wildlife habitat improvement. The direct approach improves habitat by using tools and mechanical techniques (Payne \& Copes, 1992). These structures include fences, nest boxes, dams, fish passage 
structures, and spawning beds. The indirect approach manipulates natural forces in the environment to achieve the same results. For example, increasing deer harvest reduces browsing pressure and improves habitat conditions.

Prior to 1984, improved habitat was measured using "acre equivalents" (Darden, 1993). These units measured the number of acres affected by a habitat improvement structure. For example, if a guzzler-a water entrapment device-was installed in a normally arid area, the number of surrounding acres that benefited were the "acre equivalents." In 1984, the method for measuring improved habitat was divided into two categories and now better reflects the different habitat improvement approaches: (a) actual acres improved and (b) structures. Actual acres improved includes acres on which activities such as seeding, planting, mowing, prescribed burning, and mitigation have occurred (United States Department of Agriculture, Forest Service, 1981-1992 [1987]).

\section{Total Habitat Improved}

As mentioned above, prior to 1984 the Forest Service measured improved habitat in acre equivalents. This different unit of measure explains why the number of improved acres was so much higher in the early 1980s. Instead of counting structures separately, as was the case after 1984, the number of acres benefiting from a single structure was counted along with actual acres improved (Darden, 1993). Since 1984, structures and actual acres improved have been tallied separately. During the last half of the 1980s, the number of acres remained relatively constant; yearly acre totals ranged from 124,000 to 157,000 . The number of structures built, on the other hand, nearly tripled during this same five-year period, rising from 7,500 in 1986 to over 20,000 in 1990 and 1991.

Total acres improved can be broken down into three categories: wildlife; fish; and threatened, endangered, and sensitive species. From 1985 to 1989, the number of acres improved for wildlife, which includes game and non-game species, ranged between 93,000 and 118,000 annually, and then rose in 1990 and 1991 to 128,000 and 159,000 , respectively. Acres improved for fish varied in the late 1980s, from 6,100 to 12,300 , and increased through 1990 and 1991 to nearly 14,000. Improved acres for threatened, endangered, and sensitive species ranged from 23,800 to 37,900 during the late 1980 s, and increased to nearly 58,000 in 1991 . Overall, acres improved for all three program areas varied throughout the 1980s, and rose uniformly to high levels in 1991.

Across all three program areas, the number of structures built to support wildlife increased substantially from 1985 to 1991 . For instance, the number of structures built for wildlife grew $450 \%$ during this period, from 1,800 to 8,100 . Structures for threatened and endangered species grew from 200 to 2,100 (a $105 \%$ increase) in the same period. Structures built for fish increased from 4,100 to 13,200 (a 322\% increase) between 1985 and 1990, declining a bit to 10,000 in 1991 .

\section{Habitat Improvement Methods}

Habitat improvement methods, like timber harvesting levels, differ according to region (Darden, 1993). In the East and the South, an example of improvement is creating early successional habitats for deer through timber harvesting and controlled burning. In the West, mitigation from the effects of timber harvesting is the primary method of habitat management. Protection of snags and the creation of artificial snags are examples of mitigation measures.

Late successional stage growth (i.e., older trees) suffers the most in intense timber harvesting zones, and the Forest Service claims it is attempting to pay more attention to these biologically important areas (Darden, 1993). By ensuring integrated 
resource management, prevention of mitigation has become a goal, according to a 1991 Forest Service Action Plan. In addition, an effort has been made to ensure that the resource program causing the impacts bears the cost of any needed mitigation (United States Department of Agriculture, Forest Service, 1991a).

\section{Regional Trends}

Region 1 (North), Region 5 (Pacific Southwest), Region 6 (Pacific Northwest), and Region 8 (South) are the top timber producers for the Forest Service (Farnham \& Mohai, 1995). Timber harvest levels nationally, as in these four regions, were low during the early-1980s, rising in the mid-1980s, and declining again in the late-1980s. By tracking wildlife habitat improvements in the same regions over the mid- and late-1980s, we found that the agency's traditional reliance upon mitigation as a method for habitat improvement seemed to change in 1989.

As mentioned previously, it would not be consistent to look at acres improved prior to 1984 because of the non-comparable units of measure. In 1984 and 1985 (the mid-1980s), as timber harvesting rose, so did the number of improved acres of wildlife habitat. In 1986-1988, as timber harvesting declined, so did the number of acres improved for wildlife. Since clearcutting has been the most common method of timber harvesting on National Forest lands, this trend indicates that mitigation has been the primary method for wildlife habitat improvement. This is verified by the 1987 Forest Service Report, which stated that "most" of the improved habitat was "accomplished through mitigation of impacts associated with other resource activities" (United States Department of Agriculture, Forest Service, 1981-1992 [1987, p. 28]).

The turning point seems to have been 1989 , when timber harvesting continued to decline and wildlife habitat acreage improvements rose dramatically. In 1990, the number of improved acres dropped, only to increase again in 1991 to the numbers of the mid-1980s. Intensity of harvesting pressures may continue to drop due to Robertson's directive to reduce clearcutting by $70 \%$ from 1988 levels (Robertson, 1992). With less mitigation needed, the data show that the Forest Service is employing other methods for improving wildlife habitat. As timber harvesting (in terms of both quantity and methods) become less intensive, wildlife habitat improvements will have a more positive tone. Instead of restoring habitat after it has been clearcut, methods of harvesting, such as selection cuts, and other improvement techniques, such as fertilizing clearings and reintroducing species, will be used to enhance habitat. One reason for this change may be the "significant progress in applying the information, methods and techniques" of the Wildlife and Fish Habitat Relationships System (United States Department of Agriculture, Forest Service, 1981-1992 [1989, p. 42]). By improving inventory methods and habitat evaluation procedures, this system enhances the consideration of wildlife and fisheries resources in National Forest planning and management.

\section{Programs Designed to Improve Wildlife Habitat}

Recently, a number of special initiatives have been developed for enticing the public to take a more active role in wildlife habitat improvement (United States Department of Agriculture, Forest Service, 1981-1992). These programs have enabled the Forest Service to expand both its funding base and its improvement opportunities for wildlife and fish habitat. The most prominent of these programs is the Challenge Cost-Share Program. From 1987 to 1989, projects aimed at enhancing habitat for hunting, fishing, and non-consumptive uses were developed. Conservation of threatened, endangered, and sensitive species specifically was not addressed until 1990. 
In addition to appropriated funding, Knutson-Vandenburg funding (from timber receipts), and recreational fees in five states, the Wildlife and Fisheries Program receives funding from the Challenge Cost-Share Program (United States Department of Agriculture, Forest Service, 1991b). This additional source of funding is interesting to track, as it indicates the amount of money generated from, and participation by actual users of, National Forest lands.

The Challenge Cost-Share Program, initiated by the Appropriations Act of 1986 and made a permanent program in 1991, was designed to encourage direct public involvement in the management of wildlife habitat on National Forest lands through financial resources and on-the-ground program work. It targets game, non-game, and threatened, endangered, and sensitive species (United States Department of Agriculture, Forest Service, 1991b). Since its initiation, both the amount of funding and the number of cooperators have increased substantially.

The Challenge Cost-Share Program is designed to promote direct public involvement in the management of fish and wildlife habitat. Its goal is "to maintain and enhance wildlife and fish resources on the national forests through active partnerships between the Forest Service and conservation and service organizations, other governmental agencies (Federal, State, and local), private groups, and individuals" (United States Department of Agriculture, Forest Service, 1991a, p. 6).

Congressional funding of Forest Service projects is contingent upon the receipt of matching contributions from outside sources. The JOIN US campaign was developed to invite individuals, organizations, and agencies to become Challenge CostShare Program partners. Its goal is to strengthen public-private partnerships in order to share the cost of fish and wildlife management. The results have been phenomenal: Five years after the program's inception, there were 2,380 partners (United States Department of Agriculture, Forest Service, 1992).

Other programs that reflect the Forest Service's recent emphasis on wildlife management include "Get Wild!," "Rise to the Future," and "Every Species Counts." These three programs are internal to the Wildlife and Fisheries Program, meaning that, unlike the Challenge Cost-Share Program, they do not acquire their own funding. They can be described as marketing devices to promote public involvement in wildlife habitat management activities. Unlike the Challenge Cost-Share Program, which focuses on wildlife, fish, and threatened and endangered species, each of the programs focuses on one of these three program areas (United States Department of Agriculture, Forest Service, 1992).

\section{Summary and Conclusions}

The data analysis of recreation and of wildlife and fish habitat improvement indicators reveals that both non-commodity program areas have shown an increase in activity in recent years. For the Recreation program area, recreation visitor days have increased since 1987. Recently, funds for construction and maintenance have grown substantially. Total receipts, user fees, and cost share dollars have contributed more money each year since 1987. Wilderness and Wild and Scenic rivers management has gained importance recently as an integral part of the Recreation Management program. In Wildlife and Fish habitat improvement, there have been increases recently in both total acres improved and total structures installed. Funding both from Congress and from outside sources has increased since 1986. The Wildlife and Fish Management Division has introduced a large number of new programs, some of which specifically 
target certain non-commodity programs like threatened and endangered species and nongame wildlife.

In addition, recognizing all forms of recreation-both consumptive and nonconsumptive - as highly valued uses of the National Forests, the Forest Service has reacted to improve recreational opportunities. In 1987, at the National Recreation Symposium in Wisconsin, 45 members of the Forest Service gathered, with input from all Regions, to develop the National Recreation Strategy. External input from user groups also was considered in addressing the public's recreation needs. The focus of the outcome (the National Recreation Strategy) has been to provide the "customers" with what they want from Forest Service lands (United States Department of Agriculture, Forest Service, 1988). On the side of Wildlife and Fish Management, Forest Service statements about the agency's approach to wildlife habitat improvement and evaluations by independent sources portray a more integrative approach toward managing wildlife. The Wildlife Management Institute (1990, p. 75) stated that "National Forest planning, research and resource management have improved significantly." The findings in this study support the claim that change has occurred.

The evidence indicates that the Forest Service indeed has changed in the emphasis it places on the non-commodity programs of Recreation and Wildlife and Fish Management. A concurrent study by Farnham and Mohai (1995) reveals that timber output from the National Forests has declined significantly in recent years. In addition, Farnham's (1995) budget analysis of Forest Service requests and appropriations shows a more rapid increase in funds for non-commodity line items like recreation and wildlife and fish management, than for traditional commodity line items like timber and range management. The results of this study, together with these other two mentioned above, in concert with the growing body of literature on agency change, suggest that change in the Forest Service has translated into measurable changes in the actual on-the-ground management of the National Forests.

Certainly, if there is no one statistic that can be used to measure change in the Forest Service, there are a large number of statistical indicators that can be used at least to track change in the agency. With an agency so diverse in its responsibilities and tasks, it is essential to examine many parts of its function to gain a broad perspective that is accurate for apprising a time of change. The quality of the change-whether it is for the better or for the worse-is not measurable quantitatively. However, from the evidence presented, it is now possible to ascertain where the Forest Service was and where it is headed. Such quantitative positioning is essential for any qualitative discussions that may follow.

*** *

Timothy J. Farnham is communications coordinator for the Society of American Foresters (SAF), in Bethesda, Maryland. With SAF, Mr. Farnham is responsible for forestry outreach programs and internal organization communications. He received his M.S. in natural resources policy from the School of Natural Resources and Environment at the University of Michigan in Ann Arbor, and his B.A. from Williams College, in Williamstown, Massachusetts. Research for this article was conducted while at the University of Michigan.

Cameron Proffitt Taylor works currently in the Environment Program of the Office of Technology Assessment, of the United States Congress. Ms. Taylor conducts indepth policy analysis, at the request of congressional committees, on science and technology issues related specifically to the environment. In April 1993, Ms. Taylor completed her M.S. in resource policy and administration at the University of 
Michigan's School of Natural Resources and Environment. Prior to graduate school, Ms. Taylor worked for the National Wildlife Refuge Association. This article summarizes Ms. Taylor's graduate research project.

William L. Callaway is a Washington, DC representative for the National Parks and Conservation Association, where he monitors legislation and regulations affecting National Park Service activities. Perviously, Mr. Callaway worked as a legislative assistant to Senator Harlan Mathews, and as a professional staff member for Senator Jim Sasser. In both positions, his primary responsibility was to cover environmental and energy issues. Mr. Callaway holds an M.S. from the University of Michigan's School of Natural Resources and Environment. The research for this article was conducted while Mr. Callaway was a graduate student at the University of Michigan.

\section{References}

Ackerman, S. (1990). Observations on the transformation of the Forest Service: The effects of the National Environmental Policy Act on U.S. Forest Service decision making. Environmental Law, 20 (3), 703-734.

American Recreation Coalition. (1991). Recreation today, trends and statistics. Washington, DC: Author. Congressional Research Service. (1989). Wilderness overview and statistics (89-460 ENR). Washington, DC: Author.

Darden, T. (1993, January 26). Personal communication with Tom Darden, Wildlife Program Manager, Wildlife and Fish Staff, United States Department of Agriculture, Forest Service, Washington, $D C$.

Farmer, G. (1993, February 26). Personal communication with Gerry Farmer, Budget Coordinator, Recreation Management, United States Department of Agriculture, Forest Service, Washington, $D C$.

Famham, T. (1995). Forest Service budget requests and appropriations: What do analyses of trends reveal? Policy Studies Journal, 23 (2), 253-267.

Famham, T., \& Mohai, P. (1995). National Forest timber management over the past decade: A change in emphasis for the Forest Service? Policy Studies Journal, 23 (2), 268-280.

Lundeen, D. (1993, March 12). Personal comunication with Dean Lundeen, Wild and Scenic Rivers Manager, United States Department of Agriculture, Forest Service, Washington, DC.

Mohai, P., Stillman, P, Jakes, P., \& Liggett, C. (1994). Change in the USDA Forest Service: Are we heading in the right direction? General Technical Report NC-172. St. Paul, MN: United States Department of Agriculture, Forest Service, North Central Forest Experiment Station.

Payne, N., \& Copes, F. (1992). Wildlife and fisheries habitat improvement handbook. Washington, DC: United States Department of Agriculture, Forest Service.

Rice, R. E. (1990). The importance of old-growth for biodiversity. The Ecologist, 20 (4), 143.

Robertson, D. (1992, November 19). Personal communication with Dale Robertson, Chief, United States Department of Agriculture, Forest Service, Washington, DC.

Thomas, J. C., \& Mohai, P. (1995). Racial, gender, and professional diversification in the Forest Service from 1983 to 1992. Policy Studies Journal, 23 (2), 296-309.

Twight, B. W. (1983). Organizational values and political power: The Forest Service versus the Olympic National Park. University Park: Pennsylvania State University Press.

Twiss, J. (1993, March 12). Personal communication with John Twiss, Wilderness Manager, Recreation Management, United States Department of Agriculture, Forest Service, Washington, DC.

United States Congress. (1983, September 3). House Report 98-399.

United States Congress. (1987, April 8). Senate Hearing Report 100-38.

United States Congress. (1988a, August 10). House Report 100-862.

United States Congress. (1988b, April 11). Senate Hearing Report 100-822.

United States Congress. (1988c, July 26). House Report 100-63.

United States Department of Agriculture. (1993). USDA department budget manual. Washington, DC: Author.

United States Department of Agriculture, Forest Service. (1988). America's great outdoors: National recreation strategy. Washington, DC: Author.

United States Department of Agriculture, Forest Service. (1991a). Forest Service's wildlife and fisheries action plan: The response to the Wildlife Management Institute's 1989 recommendations. 
Washington, DC: United States Department of Agriculture, Forest Service, Wildlife and Fisheries Department.

United States Department of Agriculture, Forest Service. (1991b). Challenge cost share program report 1990. Washington, DC: United States Department of Agriculture, Forest Service, Wildlife and Fisheries Department.

United States Department of Agriculture, Forest Service. (1992). A summary of USDA Forest Service's wildlife, fish, and endangered species program opportunities: Fiscal year 1993. Washington, DC: Author.

United States Department of Agriculture, Forest Service. (1981-1992). Reports of the Forest Service, fiscal years 1980-1991. Washington, DC: Author.

United States General Accounting Office. (1991). Difficult choices face the future of the Forest Service. GAO/RCED-91-115. Washington, DC: Author.

Wildlife Management Institute. (1990). Recommendations to improve wildlife and fish programs of the Forest Service. Washington, DC: Author. 
This document is a scanned copy of a printed document. No warranty is given about the accuracy of the copy. Users should refer to the original published version of the material. 